\title{
Sprawozdanie z 15. Akademii Dermatologii i Alergologii (ADA) - Hotel Mercure Gdynia Centrum, 2019
}

W dniach 7-10 lutego 2019 r. już po raz piętnasty odbyło się zimowe spotkanie alergologów i dermatologów zorganizowane przez Sekcję Dermatologiczną Polskiego Towarzystwa Alergologicznego, Katedrę i Klinikę Dermatologii, Wenerologii i Alergologii Gdańskiego Uniwersytetu Medycznego oraz Oddział Morski Polskiego Towarzystwa Dermatologicznego (PTD). W tym roku konferencja po raz pierwszy odbyła się w Gdyni. Jak zawsze to wydarzenie naukowe zostało przygotowane z myślą o wszystkich lekarzach praktykach, którzy na co dzień zajmują się leczeniem dermatoz alergicznych i chcą poznać lub przypomnieć sobie aktualne zalecenia terapeutyczne. Spotkanie zgromadziło także wielu lekarzy przygotowujących się do egzaminów specjalizacyjnych $\mathrm{z}$ dermatologii i alergologii.

Większość uczestników pojawiła się na miejscu jeszcze przed oficjalnym rozpoczęciem konferencji, aby wziąć udział w dziewięciu interaktywnych warsztatach szkoleniowych obejmujących zagadnienia z zakresu diagnostyki alergologicznej, dermatochirurgii, dermoskopii, dermatologii estetycznej oraz leczenia ran.

W spotkaniu uczestniczyło ok. 300 lekarzy z całego kraju. Wśród 60 wykładowców byli nie tylko profesorowie z ośrodków akademickich w Polsce, lecz także nasi goście i przyjaciele z Niemiec, Szwecji, Białorusi, Litwy, Łotwy, Rosji i Ukrainy, dzięki którym jubileuszowa, 15. ADA zyskała wymiar międzynarodowy. Bogaty i różnorodny program konferencji obejmował dwanaście sesji naukowych, w tym dwie sesje przypadków klinicznych. Tematyka wykładów wykraczała poza schorzenia dermatologiczne i alergologiczne i obejmowała także zagadnienia $z$ innych dziedzin medycyny. Patronat honorowy nad 15. ADA objęli Minister Zdrowia, JM Rektor Gdańskiego Uniwersytetu Medycznego (GUMed), Prezes Polskiego Towarzystwa Dermatologicznego, Prezydent Polskiego Towarzystwa Alergologicznego oraz Marszałek Województwa Pomorskiego i Prezydent Gdyni, a także Polskie Towarzystwo Medycyny Rodzinnej i Polskie Towarzystwo Pneumonologii Dziecięcej.
Uroczystego otwarcia Akademii dokonał przewodniczący Komitetu Organizacyjnego i Naukowego 15. ADA prof. Roman J. Nowicki, kierownik Kliniki Dermatologii, Wenerologii i Alergologii GUMed, który powitał przybyłych gości, przedstawicieli uczelni, władz Gdańska i Gdyni, wykładowców oraz wszystkich uczestników. Sesja inauguracyjna obejmowała cztery wykłady. $\mathrm{Na}$ wstępie prof. Lidia Rudnicka, prezes PTD, przedstawiła objaw Raynauda jako problem interdyscyplinarny. W ok. 80\% przypadków objaw Raynauda nie jest związany z żadną wspólistniejąca patologią (tzw. pierwotny objaw Raynauda). W pozostałych przypadkach istnieje ogólnoustrojowa przyczyna jego wystąpienia. Do głównych grup chorób, które powodują objaw Raynauda, należą choroby endokrynologiczne, hematologiczne i neurologiczne. Profesor Karina Jahnz-Różyk omówiła wybrane problemy anafilaksji w Polsce z perspektywy konsultanta krajowego w dziedzinie alergologii, a prezydent PTA, prof. Marek Kulus (Warszawa), przedstawił czynniki ryzyka występowania chorób alergicznych z podkreśleniem znaczenia epigenetyki. Sesję inauguracyjną zakończył wykład prof. Wojciecha Cichego z Poznania poświęcony problemom zdrowotnym największego polskiego kompozytora i pianisty - Fryderyka Chopina. Może właśnie dzięki chorobom tego muzycznego geniusza możemy powiedzieć o jego twórczości, że: „każdą swoją nutę wypełniał emocjami”. Wieczór inauguracyjny 15. ADA zakończył koncert zespołu Zagan Acoustic, wykonującego muzykę z pogranicza awangardy, jazzu i folku.

Program naukowo-szkoleniowy drugiego dnia konferencji otworzyła sesja przypadków klinicznych, a po niej odbyła się pierwsza sesja „Dermatologia bez granic”, w której usłyszeliśmy wykłady sześciu gości zagranicznych. Na początku prof. Markus Braun-Falco z Monachium przedstawił sylwetkę swojego ojca, prof. Ottona Braun-Falco, zmarłego w ubiegłym roku wybitnego niemieckiego dermatologa-alergologa, wielkiego przyjaciela młodych naukowców, twórcy stypendium dla zdolnych polskich dermatologów (stypendium OBF). Po tym emo- 


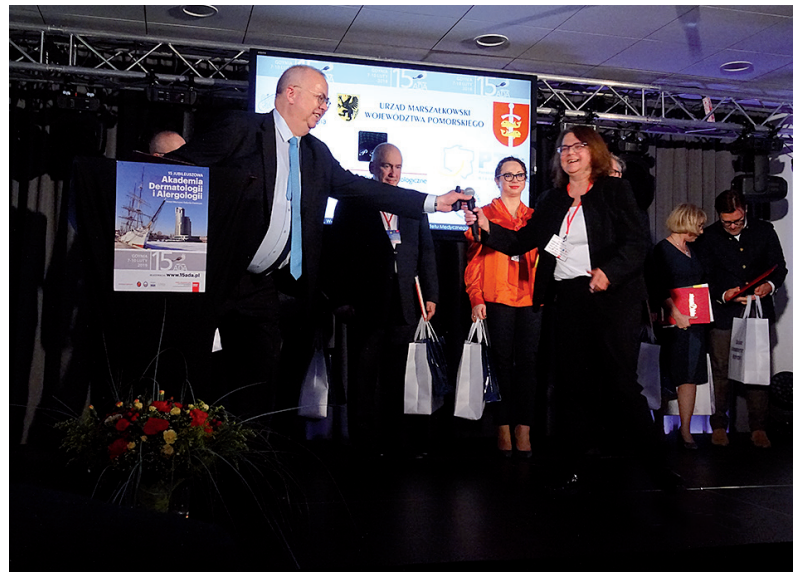

RYCINA 1. Profesorowie Lidia Rudnicka i Roman J. Nowicki podczas inauguracji 15. ADA

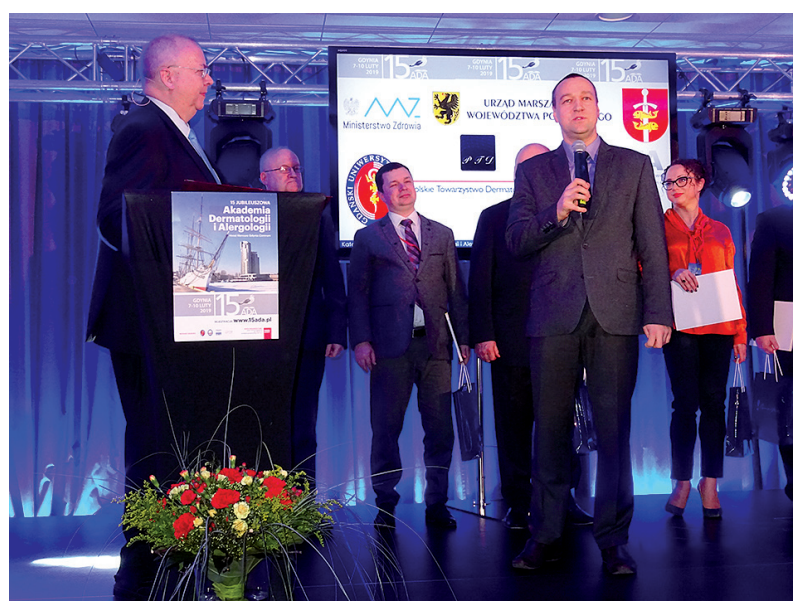

RYCINA 2. Prorektor GUMed prof. Tomasz Bączek wita uczestników konferencji

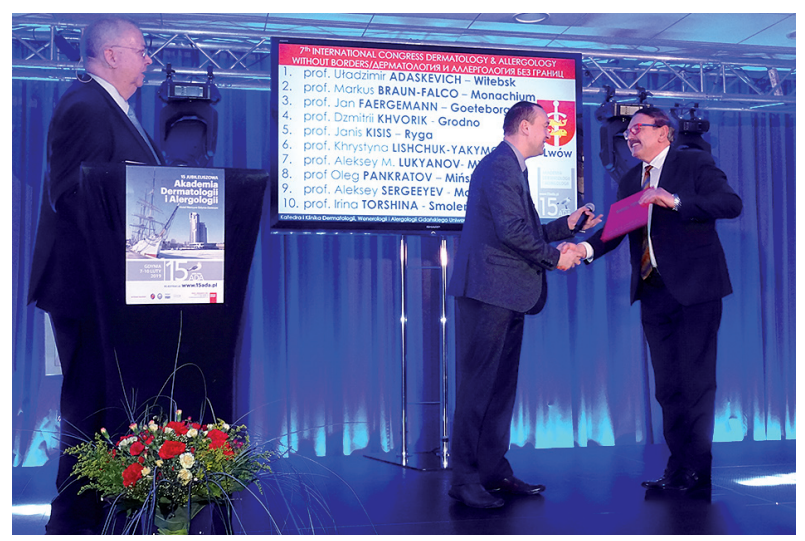

RYCINA 3. Profesor Romuald Olszański odbiera nagrodę rektora GUMed za rozdział w podręczniku „ABC pokrzywki”

cjonalnym wstępie prof. Braun-Falco omówił trudne zagadnienie autoimmunologicznych zespołów zapalnych. Kolejne wykłady przedstawili goście zza naszej wschodniej granicy. Profesor Dzmitry Khvoryk z Grodna omówił współistnienie chorób skóry z objawami ze strony innych narządów, głównie układu sercowo-naczyniowego. Profesor Marya Sergeeva z Moskwy zaprezentowała problemy kliniczne i terapeutyczne grzybicy płytek paznokciowych. Z kolei zagadnienie zmian paznokciowych jako wskaźnik różnych chorób zaprezentował prof. Oleg Pankratov z Mińska. Profesor Khrystyna Lishchuk-Yakymovych ze Lwowa zademonstrowała przypadki pacjentów z rozpoznaniem zapalenia naczyń z niedoborem dopełniacza, podkreślając trudności diagnostyczne i terapeutyczne w tym schorzeniu. Ostatni gość zagraniczny sesji - prof. Alexey Sergeev z Moskwy - omówił możliwości edukacji i rozwoju zawodowego dermatologów w Rosji oraz problem grzybicy paznokci.

W sesji „Alergologia bez granic” autorzy sześciu wykładów omówili najważniejsze problemy dotyczące pokrzywki, obrzęku naczynioruchowego oraz niepożądanych odczynów polekowych. Poznaliśmy między innymi wytyczne rozpoznawania i leczenia różnych postaci izolowanego obrzęku naczynioruchowego (dr hab. Grzegorz Porębski, Kraków). Heterogenność fenotypowa obrzęków sprawia trudności diagnostyczno-terapeutyczne. Swoiste leczenie tego schorzenia jest dostępne jedynie w przypadku dziedzicznego obrzęku naczynioruchowego z niedoboru inhibitora C1. Profesor Magdalena Czarnecka-Operacz z Poznania przedstawiła nowe i dobrze udokumentowane możliwości diagnostyczno-terapeutyczne u pacjentów z tym bardzo trudnym problemem w codziennej praktyce dermatologa i alergologa.

Kolejne dwie sesje zostały poświęcone łuszczycy. Ich głównym tematem były możliwości leczenia biologicznego tej choroby, co zostało zilustrowane przypadkami klinicznymi przez lekarzy z gdańskiej Kliniki Dermatologicznej. Wykłady doc. Anety Szczerkowskiej-Dobosz (GUMed) oraz prof. Marka Brzosko (Szczecin) dotyczyły problemu łuszczycowego zapalenia stawów (psoriatic arthritis - PsA), przede wszystkim trudności diagnostycznych. Wczesne rozpoznanie PsA i szybkie wdrożenie właściwego leczenia istotnie zwiększa szansę na zatrzymanie postępu choroby i uzyskanie remisji, jak również zmniejszenie ryzyka wystąpienia powikłań narządowych i ograniczenie kosztów choroby. U większości chorych łuszczyca skóry i/lub paznokci poprzedza średnio o 7-12 lat objawy stawowe, dlatego też do dermatologów należy badanie przesiewowe chorych w kierunku PsA.

Ostatnia sesja tego dnia była poświęcona interdyscyplinarnym problemom w alergologii. Trudnego zadania przedstawienia zagadnienia alergii pokarmowej u dzieci podjęli się prof. Mieczysława Czerwionka-Szaflarska z Bydgoszczy oraz prof. Maciej Kaczmarski z Białegostoku. Obraz kliniczny alergii pokarmowej jest zróżnicowany, a reakcje immunologiczne mogą dotyczyć każdego narządu. W związku z różnorodnymi objawami terapia 
dzieci z alergią pokarmową wymaga zawsze postępowania interdyscyplinarnego. W tej sesji dr Paweł Lipowski (GUMed) omówił zmiany oczne w przebiegu atopowego zapalenia skóry (AZS). Wykładowca zwrócił uwagę na większe w ostatnim czasie zainteresowanie występowaniem stożka rogówki w przebiegu AZS jako postępującej dystrofii rogówki oraz podkreślił rolę współpracy lekarzy dermatologów i okulistów w rozpoznawaniu i leczeniu powikłań okulistycznych w AZS. Dużym zainteresowaniem cieszył się wykład dr Joanny Renke (GUMed) na temat zasad skutecznej realizacji szczepień ochronnych u chorych $\mathrm{z}$ różnymi dermatozami, zwłaszcza w trakcie leczenia biologicznego. Sesję zakończyły trzy wykłady na temat mastocytozy ekspertów z Gdańska (GUMed): dermatologa (doc. Magdalena Lange), internisty (prof. Marek Niedoszytko) oraz hematologa (prof. Andrzej Hellmann). Rozpoznanie mastocytozy jest trudne ze względu na różnorodny obraz kliniczny związany z występowaniem objawów wywołanych przez liczne mediatory uwalniane $z$ mastocytów w procesie degranulacji. Na szczególną uwagę zasługuje postać mastocytozy układowej z towarzyszącym innym nowotworem układu krwiotwórczego. Piątkowy wieczór był okazją do spotkań towarzyskich w Starym Porcie Gdynia podczas kolacji ze wspólnym śpiewaniem pieśni żeglarskich i muzyką na żywo. Każdy uczestnik otrzymał specjalnie wydany pamiątkowy śpiewnik.

W sobotni poranek, bezpośrednio po pokazie przypadków, rozpoczęła się kolejna sesja „Dermatologia bez granic”. Tematyka wykładów tej sesji była bardzo różnorodna. Duże zainteresowanie wzbudziła prezentacja eksperta w zakresie chorób pęcherzowych - prof. Katarzyny Woźniak z Warszawy. Prelegentka podkreśliła, że autoimmunizacyjne choroby u dzieci są rzadkie, na początku ich obraz kliniczny jest do siebie bardzo podobny i wymagana jest szczególna rozwaga przy podejmowaniu leczenia immunosupresyjnego. Rzadko poruszany temat schorzeń zewnętrznych narządów płciowych wieku dziecięcego podjęła dr Monika Konczalska (GUMed), która przedstawiła obraz kliniczny oraz metody terapii najczęściej występujących dermatoz sromu u dziewczynek. Na zakończenie sesji dr Piotr Brzeziński z Ustki na przykładzie kilku jednostek chorobowych zaprezentował schorzenia dermatologiczne nieprawidłowo zdiagnozowane i leczone przez lekarzy innych specjalności niż dermatologia.

Sesję „Nowoczesna terapia” rozpoczęła prof. Małgorzata Sznitowska, która omówiła założenia koncepcji tzw. opieki farmaceutycznej. Opieka farmaceutyczna definiowana jest jako świadczenie opieki zdrowotnej udzielane pacjentowi przez uprawnionego farmaceutę, będące dokumentowanym procesem, w którym farmaceuta czuwa nad prawidłowym przebiegiem indywidualnej farmakoterapii. Pilotażowy program opieki farmaceutycznej ma

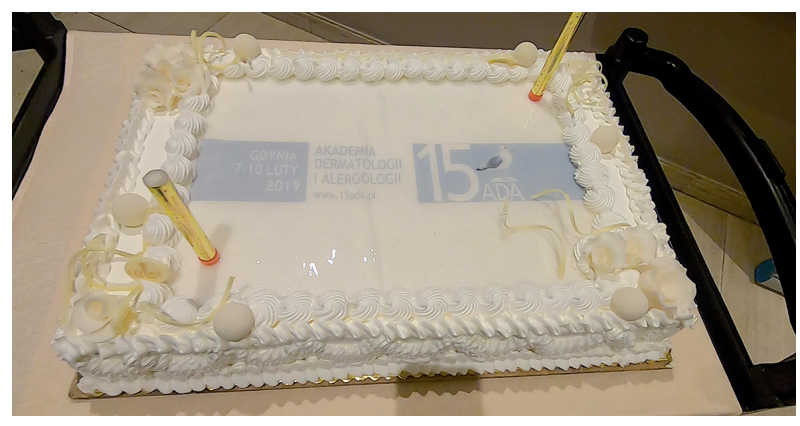

RYCINA 4. Tort jubileuszowy

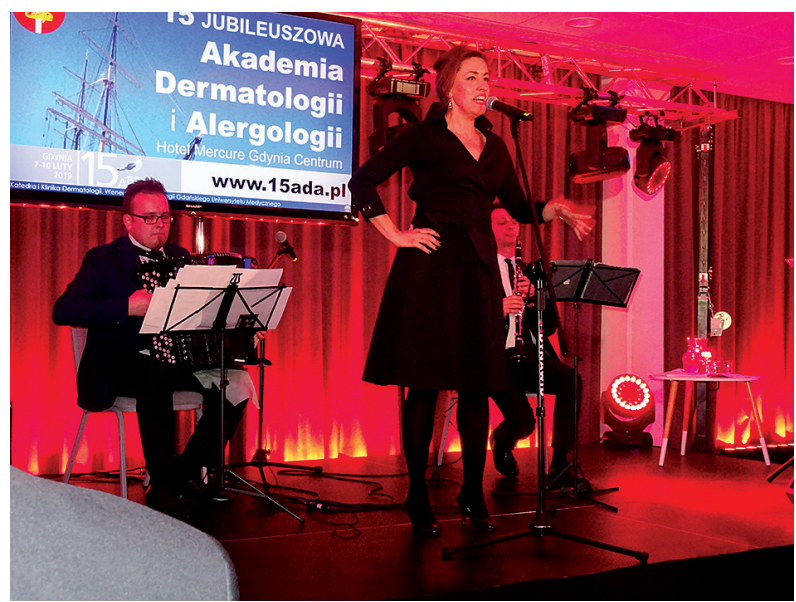

RYCINA 5. Koncert inauguracyjny

być realizowany w Polsce w 2019 r., ale należy zadać sobie pytanie, czy w aktualnych warunkach jest to realne. Dwa kolejne wykłady dotyczyły nowych możliwości leczenia biologicznego chorób dermatologicznych (dr Aleksandra Wilkowska - Gdańsk, prof. Marcin Moniuszko - Białystok). Kontynuując temat nowoczesnych terapii, prof. Małgorzata Sokołowska-Wojdyło przedstawiła nowy lek - brentuksymab wedotin (BV) - jako nadzieję na uzyskanie remisji u pacjentów w zaawansowanych stadiach mycosis fungoides i chłoniaków skóry CD30+. W Polsce czynione są starania, aby lek ten mógł być podawany pacjentom $z$ chłoniakami pierwotnie wywodzącymi się ze skóry z ekspresją CD30+ w programie lekowym NFZ.

Sesja „Postępy w rozumieniu AZS” została zdominowana przez zagadnienia dotyczące możliwości leczenia tego schorzenia. Doktor Hanna Ługowska przedstawiła trudności terapeutyczne oraz wyzwanie, przed jakim staje lekarz w obliczu ciężkiego przebiegu AZS. Konsensusy terapeutyczne są nieustannie modyfikowane w celu osiągnięcia jak największych korzyści przy jak najmniejszym obciążeniu chorego działaniami niepożądanymi leków. Profesor Roman J. Nowicki podjął się odpowiedzi na pytanie: Dlaczego potrzebujemy nowych metod terapii AZS? Ze względu na obniżenie jakości życia pacjentów i ich stygmatyzację oraz poważne konsekwencje licznych schorzeń towarzyszących (infekcje, choroby atopowe, 


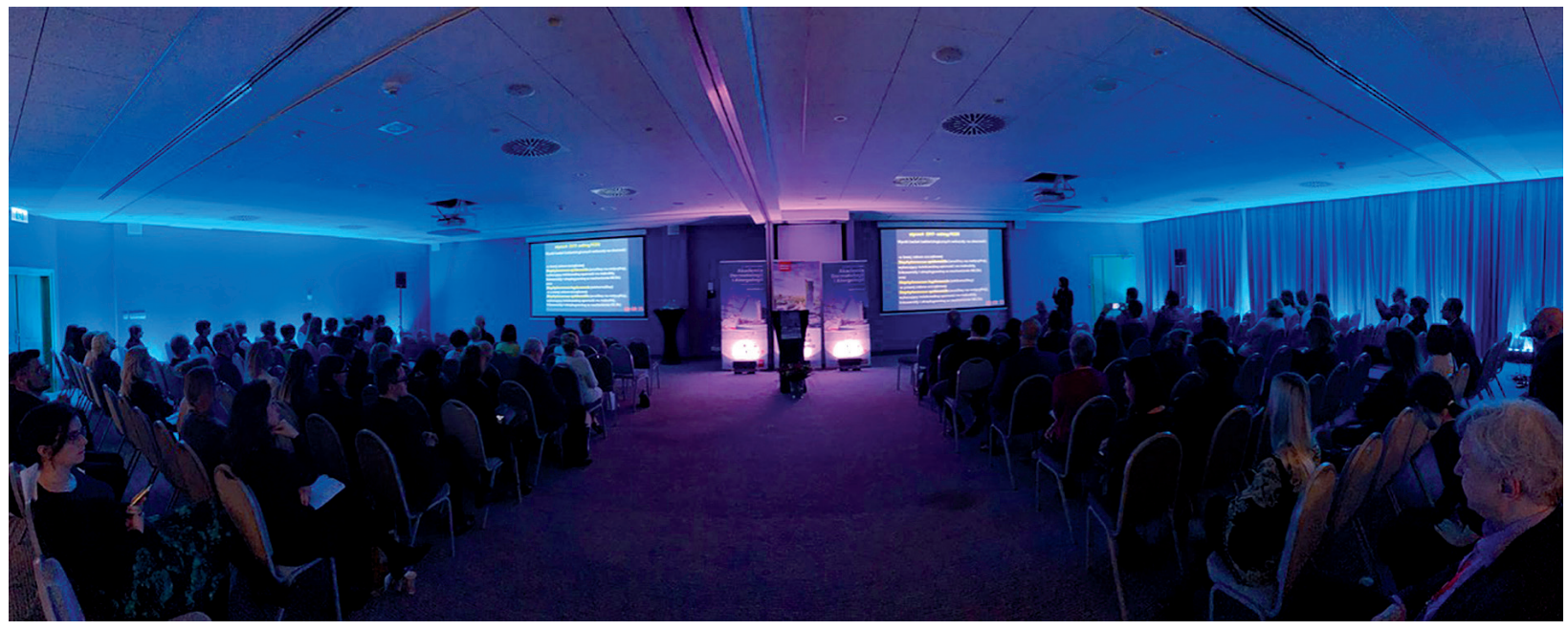

RYCINA 6. Uczestnicy konferencji w trakcie wykładu w sesji „Alergologia bez granic”

metaboliczne, kardiologiczne, zaburzenia okulistyczne, stomatologiczne i neuropsychiatryczne) konieczne jest pilne wdrożenie nowych, skutecznych leków, zwłaszcza dla chorych z przewlekłym i ciężkim AZS, u których leczenie konwencjonalne jest nieskuteczne. Na szczególne umiejscowienie zmian skórnych w przebiegu AZS zwróciła uwagę prof. Irina E. Torshina (Smoleńsk, Rosja), która omówiła różne obrazy kliniczne i trudności w różnicowaniu zmian atopowych okolic genitalnych. $Z$ kolei dr Bartłomiej Kwiek z Warszawy przedstawił zróżnicowaną etiopatogenezę i współczesne możliwości terapeutyczne świerzbiączki guzkowej. Jest to schorzenie bardzo trudne do leczenia, może powstawać spontanicznie, choć najczęściej towarzyszy innym chorobom skóry. Dotychczas nie było jednorodnych zaleceń terapeutycznych dotyczących tej choroby. W ostatnich latach pojawiły się pierwsze doniesienia o stosowaniu leków biologicznych w leczeniu świerzbiączki guzkowej i coraz więcej propozycji leków, które wpływają na neuroprzekaźniki odpowiedzialne za powstawanie świądu.

Ostatnia sesja konferencji była poświęcona infekcjom. Profesor Jan Faergemann (Szwecja) omówił trudności terapeutyczne zakażeń drożdżakowych skóry i błon śluzowych. Następnie prof. Uladimir P. Adaskevich (Witebsk, Białoruś) przedstawił sytuację epidemiologiczną kiły na Białorusi. Od początku lat 90. XX wieku w Rosji, na Ukrainie oraz na Białorusi obserwuje się stały wzrost zachorowań na kiłę. Dramatycznie pogarszają się też statystyki dotyczące kiły wrodzonej. Wyniki badań jednoznacznie wskazują, że kiła ciągle stanowi realne zagrożenie epidemiologiczne i nie można jej zaliczyć do tzw. chorób zapomnianych. Spore zainteresowanie w tej sesji wzbudził wykład prof. Wioletty Barańskiej-Rybak
(GUMed), która przedstawiła obraz kliniczny infekcji wywoływanych przez Staphylococcus lugdunensis, bakterię Gram-dodatnią, koagulazoujemną, po raz pierwszy zidentyfikowaną w 1988 r. Drobnoustrój ten najczęściej wywołuje infekcje skóry i tkanek miękkich, zapalenie wsierdzia, infekcje protez stawowych, zapalenie kości i szpiku, infekcje ośrodkowego układu nerwowego oraz infekcje układu moczowego. Patogen ten wykazuje oporność na wiele antybiotyków, $\mathrm{w}$ tym penicylinę, oksacylinę i gentamycynę. Dużą wartość dydaktyczną miał wykład dr Doroty Mehrholz (GUMed) z omówieniem przypadków pacjentów gdańskiej Kliniki Dermatologicznej, u których rozpoznano pęcherze i pęcherzyki jako objawy chorób infekcyjnych. Wśród chorób o etiologii bakteryjnej najczęściej rozpoznawano liszajec zakaźny, a w wśród chorób o etiologii wirusowej - opryszczkę zwykłą oraz wyprysk Kaposiego (eczema herpeticum - EH) u pacjentów z AZS.

W przerwach pomiędzy wykładami można było odwiedzić stoiska wydawnictw oraz firm farmaceutycznych i medycznych. Sobotni wieczór zakończyła uroczysta kolacja, która z uwagi na dużą liczbę toastów i podziękowań przeciągnęła się do niedzieli.

W niedzielę 10 lutego 2019 r. organizatorzy i goście 15. ADA obchodzili XXVII Światowy Dzień Chorego podczas specjalnej, interdyscyplinarnej sesji z udziałem JE ks. abp. Jana Pawła Lengi.

Każdy uczestnik konferencji otrzymał 27 punktów edukacyjnych potwierdzonych pamiątkowym certyfikatem.

Na kolejną, 16. Akademię Dermatologii i Alergologii zapraszamy do Gdyni już za rok, w dniach 7-9 lutego 2020 r. Szczegóły dotyczące konferencji ukażą się wkrótce na stronie www.16ada.pl.

dr n. med. Elżbieta Grubska-Suchanek 